International Journal of Business, Economics and Management

2019 Vol. 6, No. 2, pp. 111-129

$\operatorname{ISSN}(e): 2312-0916$

$\operatorname{ISSN}(p): 2312-5772$

DOI: 10.18488/journal.62.2019.62.111.129

(C) 2019 Conscientia Beam. All Rights Reserved.

check for
updates

\title{
FOREIGN DIRECT INVESTMENT - GROWTH LINKAGE IN SUB-SAHARAN AFRICA: IS GOVERNANCE A MEDIATING FACTOR?
}

\author{
Fisayo Fagbemi ${ }^{1+}$ \\ Kehinde Mary Bello
}

\author{
${ }^{1,2}$ Graduate Student of the Department of Economics, Obafemi Awolowo \\ University, Ile - Ife, Nigeria \\ Email:fisay4real@yahoo.com \\ ${ }^{2}$ Email:kennybello2008@gmail.com
}

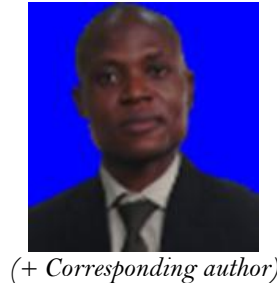

ABSTRACT

In sub - Saharan Africa, weak institutions and the rising concern for improved business environment offer considerable leverage for enhancing the effectiveness of institutional framework, capital inflows, and public investment efficiency. These have put SSA in the global spotlight in recent times. Hence, the study examines the mediating effect of governance on FDI - growth nexus in 35 SSA countries between 2002 and 2017 using panel data techniques (Pooled OLS, Fixed Effects, and Panel-Corrected Standard Error' (PCSE) estimation) and the Dynamic One - Step Difference and System GMM. Results indicate that control of corruption, political stability and regulatory quality, including governance composite index, have a positive and significant effect on economic growth, suggesting that institutions have a salutary impact on SSA economies. The findings further show that FDI inflows adversely influence growth owing to insufficient absorptive capacity that could enhance FDI effectiveness in the region. More importantly, the pervasiveness of poor governance in SSA is identified as a critical case that undermines the development of the nexus between FDI and economic growth. Thus, the study suggests that FDI - growth linkage would be enhanced by promoting a strong institutional environment that offers a good mechanism for attaining the actual FDI spillover potential through a policy framework that points the path towards cost-effective measures in SSA. Also, there should be core investment policies across African countries that would induce the private sector in consolidating government efforts and resources aimed at improving international competitiveness by diversifying the region's economies away from a protracted commodity - based.

Contribution/Originality: The study offers a sufficient basis of analysis that amplifies and consolidates FDIgovernance-growth literature. It also addresses unresolved mixed conclusions arising from puzzling methodological issues through the use of efficient and robust estimation techniques. The paper provides a better understanding of the role of governance in FDI-growth nexus regarding Africa.

\section{INTRODUCTION}

The traditional rationale for international development has been the survey-based measures of the quality of institutions and infrastructure coverage. Good institutions, public infrastructure, and capital inflows are considered as the harbinger and fundamental element of economic growth (Grossman and Helpman, 1991; Petrakos et al., 2007). The ubiquitous weak institutions and the rising concern for improved business environment mostly in developing countries offer considerable leverage for enhancing the effectiveness of institutional framework and 
public investment efficiency in these countries, especially in sub-Saharan Africa (SSA). Regarding the potential role of foreign direct investment (FDI) as the largest component of capital inflows and the key driver for investment growth in developing world (Dunning, 1994; Asiedu, 2002) many SSA countries have initiated a number of economic reforms in line with free trade and investment strategies - availability of tax incentives, simple regulatory system and provision of high-quality infrastructure, with the aim of attracting inward FDI (Abdulla $e t$ al., 2012). However, the region has not veritably experienced the dramatic increase in FDI inflows, as it only accounts for 3.4\% share of global FDI in 2016, and no African country is in the list of the top 20 countries by inward FDI flows (UNCTAD, 2017). FDI flows to Africa have continued to decline. For instance, FDI inflows in the region slumped from $\$ 57$ billion in 2015 to $\$ 53$ billion in 2016 and to $\$ 42$ billion in 2017 , down $21 \%$ from 2016 , even though are forecast to rise by about 20\% (\$50 billion) in 2018 (UNCTAD, 2018). Overall, the failure of the SSA countries in attracting huge inflows of FDI could be ascribed to the ineffective governance system and poor business environment which discourage foreign investors and leading multinational corporations $(\mathrm{MNCs})^{1}$ (Stein and Daude, 2002; Acemoglu and Robinson, 2005a) ${ }^{2}$. SSA is widely known for her poor and gloomy governance records. Investors' confidence and perception are viewed as a critical economic element (Krugman, 2009). Hence, aligning with the core view that the spillover effect of FDI on economic growth is conditional on some additional factors (especially institutional factors) within the FDI-recipient economy (Borensztein et al., 1998; Carkovic and Levine, 2003) although there is scant empirical proof that this kind of conditionality holds across countries, especially regarding SSA.

Over the years, SSA has been in the global spotlight, as many International Agencies and Non - Governmental Organizations (NGOs) have been calling for well-organized institutional reforms and good governance across countries, in view of the myriad of developmental challenges plaguing the region ${ }^{3}$, suggesting that institutions matter in economic performance (Abed and Gupta, 2002; Nondo et al., 2016). Considering the significant steps taken towards improving the African investment environment, some countries in Africa (Chad, Mozambique, Togo, Ethiopia, Ghana, Sierra Leone, Gabon, Rwanda, Zimbabwe, Niger) are among the top 20 countries, over the decade, that have tremendously improved their FDI competitiveness (Global Finance Magazine, 2018). As FDI is incentivizing by increasing protectionist tensions, foreign investors and firms have begun to see SSA as a crucial component of their growth strategies. This is majorly fuelled by the SSA countries' strong projected economic growth. In the world, the fastest growing region is forecast to be SSA over the next five years as measured by projected GDP growth rates. However, unlike developed economies, FDI inflows, in Africa, have remained unevenly distributed with only five countries (Angola, Egypt, Nigeria, Ghana, and Ethiopia) hosting $57 \%$ of their total FDI inflows (UNCTAD, 2017) ${ }^{4}$. Institutional and environmental differences could be largely responsible for this scenario, as contemporary empirical arguments appear to have supported the governmental role as mediating connection in the FDI-growth nexus.

\footnotetext{
${ }_{1}^{1}$ Owing to on-going unfavourable macroeconomic effects resulting from commodity bust and weak oil prices, major oil - (resources) dependent economies in SSA experienced a decline in their inward FDI flows in recent times, as a result of resource- and efficiency-seeking propensity of most investors, although there has been a gradual shift towards market- and strategic-seeking FDI UNCTAD, 2017. World investment report: Investment and the digital economy. United Nations Conference on Trade and Development, New York and Geneva: United Nations..

${ }^{2}$ Pointing to a contrary view, Grigoli and Mills (2014) posit that lower levels of rent seeking and corrupt practices are main reasons for lower investment levels in developed economies.

${ }^{3}$ In the context of developing and least developed countries in the world, SSA countries face most considerable challenges — ranging from structural constraints to strategic issues are, in particular, pronounced in Africa. Across the region, there has been downright low level of economic transformation UNCTAD (2018).

${ }^{4}$ Developed economies, led by the United States, the United Kingdom and France, in 2015, remained the largest investors in Africa, whilst China is one of the top 10 investors in Africa, as its FDI stock in the continent rose almost threefold between 2010 and 2015.
} 


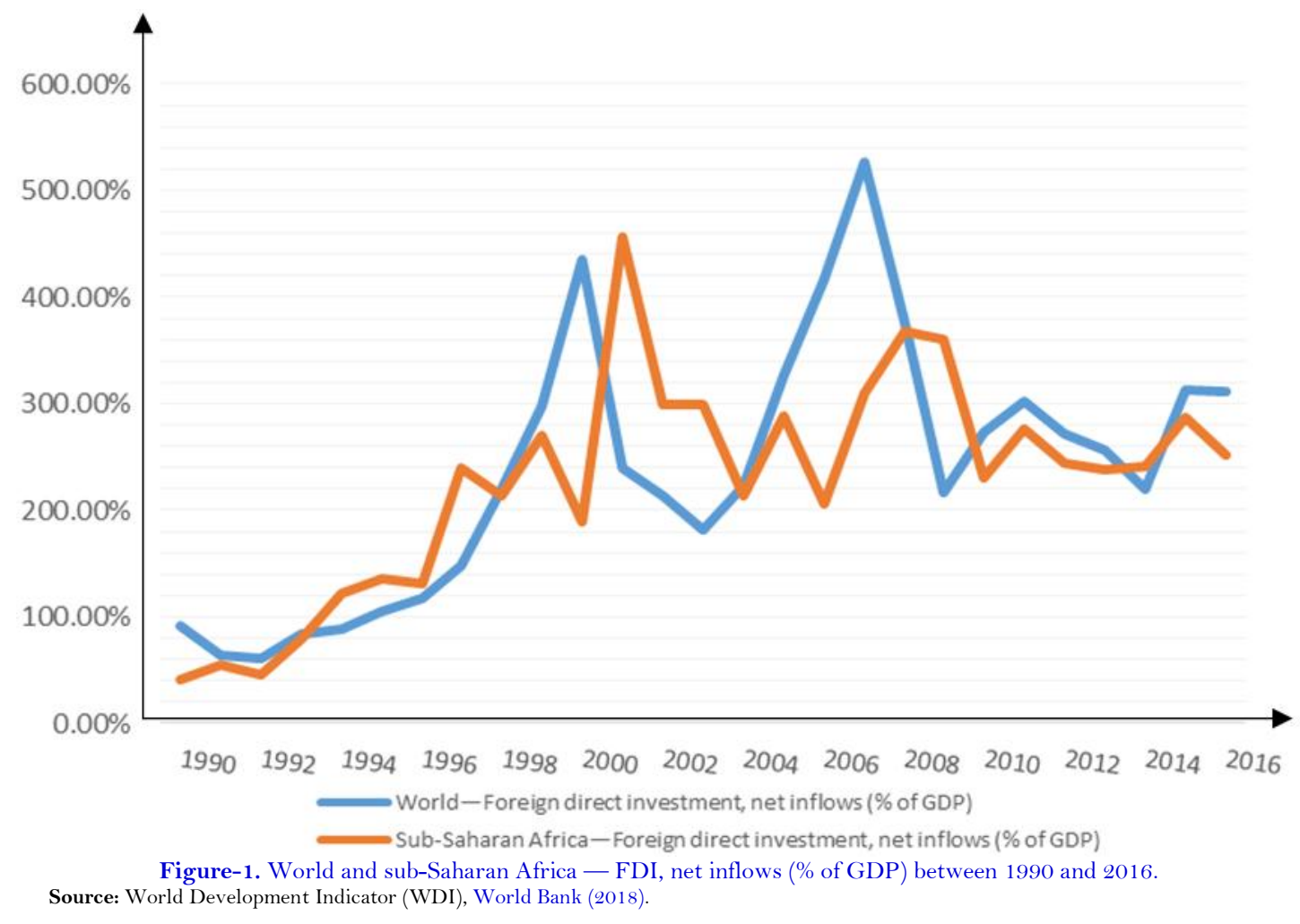

In view of the foregoing, assessing the complementary role of institutions in the FDI-growth relationship is critical. While divergent views still persist in the literature as to what constitutes the key channel through which FDI-growth nexus is transmitted, the absorptive capacity (in terms of human capacity, the level of development, financial development and sectoral pattern) forms the core and hub of major channel discourses (Dutt, 1997; Borensztein et al., 1998; Alfaro et al., 2006; Mengistu and Adams, 2007). Since most political and economic policies that enhance FDI inflows to SSA could also have a direct effect on its economic growth in the long run, the authors seem to argue that it may be more difficult to draw from the gains resulting from inward FDI, if any, than attracting FDI inflows to the region. Therefore, given the discrepant nature and uncertainty associated with the mediating link between FDI-growth nexus, a number of different propositions have emerged. One line of argument stresses that higher FDI inflows are strongly linked with good institutions (Globerman et al., 2004). In another way, Cuervo-Cazurra (2008) argues that the high costs of doing business associated with uncertainty are majorly caused by weak governance, while the more contrasting view posits that poor and bad governance system will attract more multinational companies(MNCs) to select developing economies which in turn promote growth in the respective recipient economies (Subasat and Bellos, 2013). On the other hand, the role of good institutions in the economic development process has been confirmed to be positively and significantly profound in modern economies (North, 1990; Verspagen, 2012).

Indeed, to date, in spite of the bulk of emerging contemporary views regarding FDI - governance - growth nexus, only a few empirical studies have mainly centered on the role of institutions in FDI-growth nexus in SSA. Most studies have majorly focused on either the effect of FDI on growth or the impact of institutions on economic performance. Out of the few studies on the interaction effect of institutional quality and FDI on economic growth, Hayat (2016) \& Lin et al. (2014) used a larger dataset of 106 countries (1996-2012) and 78 countries (1981 - 2005) respectively, whilst the few works specifically on SSA countries are; Ajide et al. (2014) used a dataset set for 27 countries from 2002-2012 and Adeleke (2014) on 31 countries between 1996 and 2010. In their methodological approach, a panel regression analysis was employed for SSA. Since panel regression techniques (Pooled ordinary least square, fixed effects, and random effects) are prone to possible robust errors owning to simultaneity bias and country-specific effects usually associated with macro-level studies, their findings could be shoddy and misleading, 
although both support the view that the quality of institutions matters in growth-enhancing effect of FDI in SSA. Nonetheless, Kamara (2013) explores channels that affect the FDI-growth relationship for 44 SSA countries (19812010) applying two-step System GMM, but the asymptotic standard errors associated with this approach have been proved to be severely inefficient and unbiased downward which can lead to a type II error (Windmeijer, 2005) ${ }^{5}$. As such existing findings on SSA could be viewed with skepticism because empirical discussion and intuitive claims should be accompanied by a quantitative approach and empirical proof that are adequate. Thus, with the unresolved methodological issue and given the recent change in socio-economic conditions and trade regime, the critical question is: will the same finding hold with the use of sound and most comprehensive approach?

Furthermore, based on the prevalent institutional problems in SSA countries, assessing the extent to which the quality of institutions mediates or complements FDI - growth relationship becomes imperative. As Africa only accounts for 3.4\% share of World FDI in 2016, a downright paltry share, out of the humongous increase in global FDI inflows to developing countries (UNCTAD, 2017) is the level of FDI inflows linked to SSA weak institutional environment? And also what is the joint effect of institutional quality and FDI on SSA economies? Proffering answer to these questions is the most appealing empirical puzzle. Specifically, this study seeks to explore the mediating effect of institutions on FDI-growth linkage or to put it in another way, the interaction effect of institutional quality and FDI on SSA economies between 2002 and 2017. Essentially, aside from the difference in scope from the previous studies, the study applies better and sound estimation techniques that take into account possible endogeneity and country-specific effects; one-step System - Generalized Method of Moments (GMM) estimator developed by Arellano and Bover (1995) and Blundell and Bond (1998). To enhance the robustness of results, one-step Difference - GMM, Pooled OLS, Fixed Effect and Panel-Corrected Standard Error' (PCSE) ${ }^{6}$ Estimations are also used. PCSE is well suited for this study, since time periods (T) is less than the number of Cross-section $(\mathrm{N})$, and to the best of my knowledge, no known study, regarding the topical issue, has attempted this approach.

Following the foregoing introduction, the rest of the paper is structured as follows: The immediate section covers both the theoretical and empirical review. Section three presents the methodology. Empirical results and discussion are presented in section four, whilst the concluding remarks are contained in the final section.

\section{LITERATURE REVIEW}

\subsection{Theoretical Review}

The development of the endogenous growth literature and the strong desire by researchers to give direction and guidance to policymakers prompted the question of whether FDI influences economic growth. As the theory attached much significance to human and knowledge capital (Liu and Premus, 2000) its proponents further argued that there are three important motivators of growth namely; innovation, new knowledge and public infrastructure (Romer, 1986; Lucas, 1988; Grossman and Helpman, 1991). They all support the view that FDI can be a strong predictor of economic growth and that, in contrast to the neoclassical views ${ }^{7}$, policies exert considerable influence on the growth of any economy in the long run (Petrakos et al., 2007). Albeit, the foremost initiative on the relationship between institutions and economic growth can be traced back to North (1990) who emphasizes that the quality of institutions matters in economic growth through the impact of institutional framework on economic

\footnotetext{
${ }_{5}^{5}$ The one - step System GMM estimator, given the asymptotic standard errors, is virtually efficient and unbiased compared to the two - step GMM.

${ }^{6}$ For a detailed discussion of PCSE (see, Parks (1967)) — in a system of regression equations, it ensures efficient estimation when disturbances give both serial and contemporaneous correlation.

${ }_{7}$ The main representatives of neoclassical school are; Alfred Marshall (1842 - 1924), Irving fisher (1867 -1947) Leon Walras (1834- 1910) and among others. According to them, factors of production (land, labour and capital) are independent factors of the formation of national product, whilst the income received by owners of these factors are determined by their marginal product.
} 
development. The author is the main protagonist of new institution economics (NIE) theory ${ }^{8}$. Furthermore, according to Acemoglu et al. (2005b) in terms of income and economic development, differences between countries could be explained by institutional differences. With respect to the enforcement and promotion of property rights, in an environment of low confidence, firms tend to be of a small number and keep adopting methods that are less capital - intensive and with a short - term horizon operation.

On the FDI-growth nexus, given the role of institutions, knowledge spillover serves as the first and the most significant effect of FDI on the host country's economic performance, as it occurs through the imitation of the domestic firm the multinational enterprises' (MNEs) demonstration of technology, competition and skilled labour (Crespo and Fontoura, 2007). They also argue that good institutional quality such as lack of corruption, effective governance system and rule of law, can stimulate healthy competition between foreign and local firms. However, poor institutions can give rise to unbearable costs and higher risk, and thus lowering the level of investment of foreign firms in any country. In addition, high transaction costs necessitated by the pervasive bribery in the system, tedious bureaucratic process, and rent-seeking behaviour have an indirect influence on the growth of the economy by discouraging investment. Political freedom and government effectiveness mostly account for differences in capital accumulation and labour productivity (Hall and Jones, 1999). Generally, the quality of institutions is vital for the realization of knowledge spillover.

Another very crucial channel of effect is that FDI is expected to stimulate competition in the industrial sector (Blomstrom and Kokko, 2003; Driffield and Love, 2007) which in turn leads to greater innovation and efficiency. This will enable the domestic firms to cope with the challenge of intense competition. On the other hand, through capital accumulation, FDI also affects economic growth, although based on the quality of institutional factors. Foreign investors will be encouraged by good institutions to invest in firms and industries with a low number of local firms (Hayat, 2016). Hence, greater capital accumulation will be attained in the sector that is in need of such attention. Many other factors that determine the effect of FDI on economic development have also been identified in the literature. These include; financial market development, open trade regime and business environment (Balasubramanyam et al., 1996; Durham, 2004). Finally, it can be deduced that the FDI-growth relationship is typically conditional on the state of institutions and certain circumstances in the recipient country.

\subsection{Empirical Review}

Findings on foreign direct investment and institutions have not gone without offering anecdotal evidence on their respective roles in the economic development process. This reflects that the relationship between institutions, foreign direct investment and developing economies has been explored with several different approaches. While the significant contribution of both FDI and institutions to growth is embedded firmly in empirical arguments, there is paucity of work, however, on the joint effect of FDI and institutions on economic performance, specifically in SSA. Nonetheless, numerous empirical postulations have given much insights on the potential role of FDI inflows and institutional quality towards economic performance across countries (Acemoglu et al., 2001; Chauvet and Collier, 2004; Wang and Wong, 2009; Gui-Diby, 2014; Pegkas, 2015; Behera and Dash, 2017). An essential component necessary for reference, aside from the direct effect, there also exists a multiplier effect of both institutions and FDI on economic growth. As stressed by some scholars, FDI could induce technological change and enhance technological improvements following the adoption of foreign technology and technological spillover and knowhow, thus boosts in exports (Ray, 2012). In contrast, some believe that FDI could bring about the crowding-out effect on domestic investment through the destructive competition of foreign affiliates with local firms and "market stealing effect" owing to absorptive capacity (Spencer, 2008; Wan, 2010). Overall, while it is worth noticing that the empirical assessment is most efficient to take into account the direct impact of FDI on economic growth, it is not

${ }^{8}$ The theory (NIE) stresses that institutional framework is critical, and serves as a veritable tool in the growth of any economy (see Williamson (1985)). 
sufficed to fully capture the multiplier effect on the economy. Institutional changes, in today's view, are central for driven modern economies as against capital accumulation (Sarwar et al., 2013).

Concerns regarding the relationship between FDI and economic growth ${ }^{9}$ are not new. For example, Choe (2003) using a mixed fixed Granger causality test of Holtz-Eakin approach shows that FDI Granger causes economic growth in 24 developing countries investigated $(1971-1995)$. On the other hand, although with the same approach, Al-Iriani (2007) finds a bi-directional causality between FDI and economic growth in Bahrain, Kuwait, Oman, Saudi Arabia and United Arab Emirate (UAE) over the period of 1971-2004. Also in the work of Chowdhury and Mavrotas (2006) using a panel of Lag Augmented Vector Auto Regressive (LAVAR), the results show that there is a bidirectional causality between FDI and economic growth in three countries (Chile, Malaysia, Thailand) examined from 1969 - 2000. However, Duttaray et al. (2008) following data from 66 developing countries to examine the causality between FDI and economic growth. In 29 of these countries, it is found that the direction of causality only runs from FDI to growth. Pegkas (2015) examines the relationship between FDI and economic growth for Euro Zone countries over the period of 2000-2012 by employing panel data estimations with fully modified ordinary least square (FMOLS) and Dynamic Ordinary Least Square (DOLS). The author posits that there is a positive long-run relationship between FDI and economic growth. Similarly, Jugurnath et al. (2016) adopting both static panel regression technique and dynamic panel estimate on 32 sub-Saharan African countries between 2008 and 2014. The empirical evidence suggests that the impact of FDI on economic growth is positive and significant. Others studies on developing countries that also support the positive impact of FDI on economic growth include; Sylwester (2005); Li and Liu (2005); Sunde (2017) and among others.

However, in spite of numerous empirical arguments in support of the positive effect of FDI on economic growth, there are several other findings that suggest the opposite. It is emphasized that since multinational companies can compete in local resource market, they may displace indigenous firms, and in turn, affect growthFDI may crowd out local firms in the product market (De Backer and Sleuwaegen, 2003). Moreover, based on the Error Correction Model (ECM) approach, Akinlo (2004) examines the effect of FDI on economic growth in Nigeria for the period of 1970-2001. The findings indicate that both foreign capital and private capital have a little and not statistically significant effect on growth. The author supports the argument that extractive FDI might not fuel the engine of growth as much as manufacturing FDI. Similarly, Shaikh and Shar (2010) using ordinary least square regression posits that FDI is significantly positive in the manufacturing sector. Studies by Fosu and Magnus (2006) employing bound test (ARDL) approach to cointegration between 1970 and 2002 on Ghana's economy indicate that FDI negatively affects growth whilst Yalta (2013) using simulation-based inference and maximum entropy-based approach to avoid pre-test shows that there is no statistically significant relationship between FDI and economic growth in China (1982-2008).

According to Carkovic and Levine (2003) the macro-level positive findings of FDI on economic growth ought to be viewed with skepticism. Their arguments were based on the fact that most of the studies failed to control for simultaneity bias and country-specific effects. Hence the authors employ the generalized method of moments (GMM) technique to control for the aforementioned shortcomings in 72 countries from 1960 to 1995. Their findings reveal that the exogenous component of FDI does not have a robust positive influence on growth. However, using System-GMM proposed by Blundell and Bond (1998), Gui-Diby (2014) assesses the impact of FDI on economic growth in 50 African countries during the period from 1980 to 2009. The study indicates that FDI inflows have a significant impact on economic growth in the African region during the period. Thus, these seem to show the ambiguous role of FDI in economic growth process (Greenaway and Kneller, 2007). Going by a recent

\footnotetext{
${ }_{9}$ The most systematized and comprehensive literature review on the effect of FDI on growth between 1994 and 2012, from all sources explored, could be traced to Almfraji and Almsafir (2014). In their work, they did a thorough review. They largely show that there are instances where studies stress that there is no, or even an adverse, impact.
} 
literature survey by Bruno and Campos (2013) they reveal that 11\% of empirical works find an adverse effect of FDI on growth, $50 \%$ report a significantly positive influence of FDI on economic growth, whilst $39 \%$ find that economic growth is independent of $\mathrm{FDI}^{10}$.

On institution - growth nexus, Mehanna et al. (2010) using panel data on 23 MENA countries over the period of 1996-2005. They made use of various institutional indicators (voice and accountability, government effectiveness and control of corruption). Their findings reveal that all the institutional indicators are found to exert a robust economic impact on economic development. With another set of institutional variables (civil liberties, quality of government), Valeriani and Peluso (2011) assess the impact of institutional quality on economic growth between 1950 and 2000 employing panel data pooled regression and fixed effects model on 181 countries. The results also support the positive effect of intuitional quality on growth. Studies by Zouhaier and Kefi (2012) applying static panel data model on a set of 37 developed and developing countries (1975-2000) indicate institutional quality variables (civil liberties and political rights) have positive effects on economic growth, Alexious et al. (2014) focus on the extent of the use of conventional methods, in most of relevant growth studies, can successfully provide interpretation on the economic performance of a highly underdeveloped African country such as Sudan. Accordingly, they apply ARDL bound test approach to cointegration. The empirical results reveal that, for the Sudanese economy between 1972 and 2008, in defining economic prosperity, the quality of the institutional environment is one of the most crucial factors. However, some researchers have found institutional quality variables do not have an influence on growth. For instance, in the work of Dollar and Kraay (2000) empirical evidence indicates that there is a modest adverse relationship between democracy and growth through the incorporating impact of economic freedom. On the other hand, in the study of Sayan (2009) applying both the fixed and random effect model to assess the impact of corruption on economic development measured by GDP per capita for MENA and Latin American Countries (1993-2003). While results indicate that corruption is associated with improved economic growth in MENA countries, it does not have any significant effect on growth in Latin American countries.

Based on the joint effect of institution and FDI on economic performance, focusing on seven ECOWAS countries between 1996 and 2010, Raheem and Oyinlola (2013) using ordinary least square and threshold autoregressive (TAR) models. They find that both FDI and governance are positively related to growth in the linear regression (OLS) whilst for the non - linear model (TAR), the positive effect (s) of FDI would start to manifest once governance reaches a threshold level of -1.2. In addition, in conditioning the direct benefits of FDI, they support the significance of sound and robust macroeconomic policies. On the growth-enhancing effect of FDI, Lin et al. (2014) examine the significance of institutions using a panel of 78 countries and system GMM over the period of 1981 - 2005. The imposition of an interaction term between FDI and institutional quality captures the mediation effect. Based on the complementary relationship between FDI and institutional quality ${ }^{11}$, the findings reveal that the impact of FDI on growth indeed depends on the institutional quality in the host countries. Hayat (2016) examines both the direct and indirect role of institutional quality in economic development process applying the instrumental variable model to a larger dataset of 106 countries $(1996-2012)$. The author posits that except for the rule of law, both aggregate institutional quality variable and individual variables have a small but significant direct effect on economic performance through boosting FDI. More importantly, Ajide et al. (2014) focus on the interaction effect of institutional quality and FDI on economic growth in SSA between 2002 and 2012 employing a dataset set for 27 countries. The results obtained indicate that the quality of institutions matters in the growth-

\footnotetext{
${ }_{10}$ The major outcomes generated from various empirical arguments are the discrepancies and conflicting results in the existing literature.

${ }^{11}$ Many studies support the notion that institutional quality is paramount to FDI Daniele and Marani (2006), Mishra and Daly (2007), Masron and Nor (2013). In contrast, Onyeiwu and Shrestha (2004); Subasat and Bellos (2013); Nondo, Kahsai and Hailu (2016) fail to confirm any significant link between FDI and institutional factors.
} 
enhancing effect of FDI. Analogously, Adeleke (2014) using panel regression analysis in 31 SSA countries show that there is a positive joint effect of FDI and institutional quality on economic growth in the region.

In summary, the explanation for these findings could be viewed with skepticism, as most techniques used did not account for simultaneity bias and country-specific effects usually associated with macro-level studies, especially regarding the complementary relationship between institutions and FDI. Specifically, based on the review, few studies that centered on the joint effect of institutional factors and FDI on SSA economies failed to address the aforementioned shortcomings with the absence of a comprehensive approach that can serve as a potential vehicle in eviscerating uncertainties. Thus, such inadequacies can produce shoddy conclusions. Although most empirical evidence seems to converge on the theoretical proposition that the effect of FDI on the growth of any economy is relatively conditional on certain circumstances, conflicting results have pointed to different methodological issues. Some researchers have shown interest in examining the indirect role institutions play in the economic development process through the channel of foreign direct investment in SSA, but with scant attention and tenuous methodological approach. Hence, the increasing need to address these discrepant (unresolved) methodological imbalances and seemingly untenable and conflicting empirical conclusions, regarding sub-Saharan African countries, through research techniques that offer the most comprehensive and reliable approach. Basically, applying a battery of recent econometric techniques is yet another crucial novelty that the current study develops on the FDI - institutional quality - growth debate in Africa, particularly SSA.

\section{DATA AND METHODOLOGY}

\subsection{Data}

In line with the main objective of the study, thirty-five (35) SSA countries are studied between 2002 and 2017. The choice of scope was basically determined by the availability of data, particularly for the institutional measures which represent one of the key variables of interest. Specifically, given that most SSA economies are mainly commodity - based, the scope covers both the period of low and high global commodity prices. The selection of countries was also guided by the availability of data. Six institutional indicators based on the work of Kaufmann $e t$ al. (2010) ${ }^{12}$ were used. The composite index (aggregate governance measures) was obtained using principal component analysis (PCA) with all the six measures included, whilst three (control of corruption, political stability and regulatory quality) individual governance variables were also incorporated in the model since they are separate inter-connected parts. The governance variables capture perceptions of the quality of public institutions, possibility that the government will be overthrown or destabilized, extent to which a country's citizens are free to participate in the selection of their government, the level of public (political) power and how it is used for private gain and particularly the quality of contract enforcement. Other variables used in the model are; real GDP per capita (constant 2010 US $\$$ ) which represents economic growth, and it is denoted by $Y$. Following the theoretical argument that the FDI, as denoted in the model, is a source of capital accumulation and technological progress, it is used in place of foreign stock of capital whilst gross capital formation (\% of $G D P)-G C F$, represents the domestic stock of capital. Trade Openness (TRP) is also used to capture the extent of the global influence on SSA economies. GCF and $T R P$ are the control variables. $F D I$ is the foreign direct investment, net inflows (\% of GDP). More importantly, governance composite index is denoted as $G O V$, while the three individual governance measures incorporated is given as; COR (control of corruption), POL (political stability) and REG (regulatory quality). Aside from data on governance system that were sourced from World Governance Indicators (WGI), WB (2018) all others were obtained from the World Development Indicator (WDI), WB (2018).

\footnotetext{
12 Following the study of Kaufmann, Kraay and Mastruzzi (2010) the index of institutional quality measures (i.e. control of corruption, government effectiveness, rule of law, political stability, regulatory quality and voice and accountability), ranging from -2.5 to 2.5 , were employed. Higher values of these indexes indicate a higher level of institutional quality, while lower levels suggest a decrease level of institutions
} 
3.2. Methodology

The estimated equation in this study is informed by the work of Borensztein et al. (1998); Carkovic and Levine (2003); Mengistu and Adams (2007); Ajide et al. (2014) and based on the prior theoretical exposition, the empirical model on FDI-growth nexus through governance channel is specified as:

$$
Y_{\mathrm{it}}=f\left(F D I_{\mathrm{it}}, G O V_{\mathrm{it}}, F D I_{\mathrm{it}} * G O V_{\mathrm{it},} X_{\mathrm{it}}\right)
$$

Where FDI * GOV indicates the interaction term between governance system and FDI. The vector of the control variables $(G C F \& T R P)$ is represented by $X_{x}$ while $i$ and $t$ are time periods and countries respectively. $Y, F D I$, and $G O V$ remain as defined previously.

More explicitly, Equation 1 is rewritten as follows:

$$
Y_{\text {it }}=\alpha_{0}+\beta_{1} F D I_{\text {it }}+\beta_{2} G O V_{\text {it }}+\beta_{3}\left(F D I_{\text {it }} * G O V_{\text {it }}\right)+\beta_{4} X_{\text {it }}+\mu_{i}+\varepsilon_{\text {it }}
$$

$\alpha_{0}$ is the constant while $\beta_{1}{ }^{s} s$ represent the unknown parameters. $\varepsilon$ indicates the error term component. The country - specific effect is represented by $\mu_{i}$, and it is assumed to be time unvarying.

Since it is necessary to take into account the heterogeneity issue owing to dissimilarities among countries, and the possibility of dynamic information case in the panel data model, which may cause endogeneity problem between economic growth and explanatory variables. Hence, the transformation of Equation 2 is stated as;

$$
Y_{\text {it }}-Y_{\text {it }-1}=\alpha_{\mathrm{t}}+\beta_{0} Y_{\mathrm{it}-1}+\beta_{1} F D I_{\mathrm{it}}+\beta_{2} \operatorname{GOV}_{\mathrm{it}}+\beta_{3}\left(F D I_{\mathrm{it}} * G O V_{\mathrm{it}}\right)+\beta_{4} X_{\mathrm{it}}+\mu_{\mathrm{i}}+\varepsilon_{\mathrm{it}}
$$

The growth rate of SSA economies is represented by $Y_{\text {it }}-Y_{\text {it }-1}$ and in order to account for the possible uniform change to all, $\alpha_{t}$ is taken as period-specific effect. Furthermore, the country-specific effect $\left(\mu_{i}\right)$ in Equation 3 is eliminated by taking its first differences with a view to controlling for the country-specific effect. As such, the estimated model is given as Equation 4;

$$
\Delta Y_{\text {it }}=\Delta \alpha_{t}+\left(\beta_{0}+1\right) \Delta Y_{\text {it }-1}+\beta_{1} \Delta F D I_{\text {it }}+\beta_{2} \Delta G O V_{\text {it }}+\beta_{3} \Delta\left(F D I_{\text {it }} * G O V_{\text {it }}\right)+\beta_{4} \Delta X_{i t}+\Delta \varepsilon_{\text {it }}
$$

Given the likelihood of $Y_{i t-1}$ to be endogenous to the error terms through $\left(\varepsilon_{i t-1}\right)$, as argued by Arellano and Bover (1995) in addressing the endogeneity issue, time and country-specific effect should be both controlled for. Thus, as instruments for equations in levels, lagged first-differences are used together with usual techniques (system - GMM).

More specifically, different estimation procedures are employed (one - step Difference and System GMM ${ }^{13}$, Pooled OLS, Fixed Effect and Panel - Corrected Standard Error' (PCSE) Estimation) with a view to ensuring the robustness of results. Through standard diagnostic tests, the appropriate approach on a given dataset is usually produced consistent and unbiased estimates. Although system-GMM has been commonly viewed as the most efficient and reliable estimation method in case of the dynamic panel and even with the short sample period, by

\footnotetext{
${ }_{13}^{3}$ Both system and difference GMM are general estimators developed for cases with "Small T" "Large N" panels (i.e. time periods and many cross-sectional observations). However, compared to System GMM, the Difference GMM estimator does not perform well where there is presence of highly persistency among variables Roodman (2009).
} 
applying different techniques will eliminate possible estimation errors and shortcomings often associated with the tenuous approach. Indeed, this study will offer an adequate template for attaining and arriving at empirically tenable conclusions.

\section{EMPIRICAL RESULTS AND DISCUSSION}

Based on the prior theoretical discussion, FDI and institutional measures are expected to have a positive correlation with the SSA economies, as foreign investors usually seem to outperform domestic producers in terms of productivity and direct export share in the region (foreign firms have higher productivity potential compared to domestic firms $)^{14}$. However, owing to factors impeding the effective transmission channels, African economies may not fully internalize and embrace positive spill-overs. While promoting a strong institutional environment offers a good mechanism for attaining the actual FDI spillover potential, but such proactive government policies across SSA countries could be limited by huge capacity gaps. A positive sign is also expected for trade openness, yet it is well understood that if no linkage exists between critical sectors of the economy, the result of exports from the primary sector may not have the clear effect on the rest of the economy. Finally, gross domestic capital formation is also expected to have a positive relationship with economic, since it is one of the key production factors.

Table 1 presents the result of the Pooled OLS and Fixed effects based on the model specification. In this study, the Hausman test substantiates the appropriateness of the fixed effects in the model. Each column (i - iv) represents governance index, control of corruption, political stability and regulatory quality respectively. The pooled OLS estimations (column i - iv) suggest a negative significant coefficient for FDI while institutional measures have a positive significant effect, with the exemption of governance index with insignificant influence on economic growth in SSA. Overall, the impact of regulatory quality (column iv) is more pronounced. These results are indeed in tandem with studies of Fosu and Magnus (2006) for Ghana; Yalta (2013) for China, who support the view that FDI retards growth ${ }^{15}$ in the two countries respectively. On the other hand, this conclusion also validates the findings of Valeriani and Peluso (2011) for 181 countries; Mehanna et al. (2010) for 23 MENA countries, that institutions exert robust influence on economic growth. For the control variables, Trade openness exhibits a positive and significant effect on growth in the model. However, gross domestic capital formation, although has a positive link with growth, except in column (iv), is statistically insignificant. Curiously, the major parameters of interest- the interaction terms of FDI and governance measures, have an adverse effect on SSA growth, but they are significant in column (ii) \& (iv) respectively. In contrast, only in column (iii) - FDI*POL - there is a positive but insignificant effect on growth. What may explain the adverse mediating effect? In the short term, weak governance capacity and implementation as well as the absence of institutional coordination resulting to limited investment reduced exports and employment could be a key factor (Pedersen and McCormick, 1999; Meyer and Sinani, 2009) ${ }^{16}$.

As discussed, coefficients could be inconsistent and biased, as the imposition of homogeneity constraints on the data are extreme. As a basis for comparison, the fixed effects estimator reproduces the model 2 results. While heteroskedasticity and autocorrelation case have been accounted for, the parameters of key regressors (FDI*COR $\left.F D I^{*} P O L \&^{\circ} F D I^{*} R E G\right)$ are highly significant and positive, but the interaction of the FDI with governance index $\left(F D I^{*} G O V\right)$, although significant, is negative.

\footnotetext{
${ }^{14}$ See Farole and WinklerMaking (2014).

${ }_{15}$ Comparing the results with those of Adeleke (2014), Ajide, Adeniyi and Raheem (2014) for SSA, as they both found that FDI positively affects growth in the region, the difference in results can be attributed to different time frame and methodological approach.

${ }^{16}$ On the contrary, there is no evidence that the degree of corruption affects the extent of FDI spillovers in 17 emerging countries (see Gorodnichenko, Svejnar and Terrell (2007).
} 
Table-1. Pooled OLS and Fixed Effects Estimation.

\begin{tabular}{|c|c|c|c|c|c|c|c|c|}
\hline GDP $(\log )$ & & Pool & OLS & & & Fixed & ffects & \\
\hline & (i) & (ii) & (iii) & (iv) & (i) & (ii) & (iii) & (iv) \\
\hline$F D I$ & $\begin{array}{c}-0.03 * * * \\
{[-4.51]}\end{array}$ & $\begin{array}{c}-0.10^{* * * *} \\
{[-5.43]}\end{array}$ & $\begin{array}{c}-0.05 * * * \\
{[-4.60]}\end{array}$ & $\begin{array}{c}-0.08 * * * \\
{[-5.80]}\end{array}$ & $\begin{array}{l}-0.005 \\
{[-0.73]}\end{array}$ & $\begin{array}{l}0.02 * * \\
{[3.14]}\end{array}$ & $\begin{array}{c}0.006 * * \\
{[2.55]}\end{array}$ & $\begin{array}{l}0.01 * * \\
{[3.52]}\end{array}$ \\
\hline$T R P(\log )$ & $\begin{array}{l}0.23 * * * \\
{[12.19]}\end{array}$ & $\begin{array}{l}0.71 * * * \\
{[14.08]}\end{array}$ & $\begin{array}{l}0.57 * * * \\
{[18.72]}\end{array}$ & $\begin{array}{l}0.43 * * * \\
{[11.71]}\end{array}$ & $\begin{array}{c}0.03 \\
{[0.13]}\end{array}$ & $\begin{array}{c}0.06 \\
{[0.76]}\end{array}$ & $\begin{array}{c}0.03 \\
{[0.93]}\end{array}$ & $\begin{array}{c}0.04 \\
{[1.10]}\end{array}$ \\
\hline$G C F(\log )$ & $\begin{array}{c}0.23^{*} \\
{[1.88]}\end{array}$ & $\begin{array}{c}0.14 \\
{[0.38]}\end{array}$ & $\begin{array}{c}0.03 \\
{[0.28]}\end{array}$ & $\begin{array}{l}-0.002 \\
{[-0.30]}\end{array}$ & $\begin{array}{l}0.14 * * \\
{[2.95]}\end{array}$ & $\begin{array}{l}0.05 * * \\
{[3.38]}\end{array}$ & $\begin{array}{l}0.07 * * \\
{[2.89]}\end{array}$ & $\begin{array}{l}0.05 * * \\
{[3.10]}\end{array}$ \\
\hline$G O V$ & $\begin{array}{c}0.39 \\
{[1.22]}\end{array}$ & & & & $\begin{array}{c}0.02 * * * \\
{[7.13]}\end{array}$ & & & \\
\hline COR & & $\begin{array}{c}0.14^{* * * *} \\
{[5.11]}\end{array}$ & & & & $\begin{array}{c}0.12 \\
{[0.40]}\end{array}$ & & \\
\hline POL & & & $\begin{array}{c}0.13 * * * * \\
{[3.43]}\end{array}$ & & & & $\begin{array}{l}0.04 * \\
{[1.62]}\end{array}$ & \\
\hline$R E G$ & & & & $\begin{array}{c}0.80^{* * * *} \\
{[9.68]}\end{array}$ & & & & $\begin{array}{c}0.11 * * * \\
{[5.12]}\end{array}$ \\
\hline$F D I^{*} G O V$ & $\begin{array}{c}-0.01 \\
{[-0.82]}\end{array}$ & & & & $\begin{array}{c}-0.03 * * * \\
{[-4.31]}\end{array}$ & & & \\
\hline$F D I^{*} C O R$ & & $\begin{array}{c}-0.03 * * * \\
{[-3.77]}\end{array}$ & & & & $\begin{array}{c}0.02 * * * \\
{[9.18]}\end{array}$ & & \\
\hline$F D I * P O L$ & & & $\begin{array}{l}0.002 \\
{[0.11]}\end{array}$ & & & & $\begin{array}{c}0.01 * * * \\
{[5.03]}\end{array}$ & \\
\hline$F D I * R E G$ & & & & $\begin{array}{c}-0.13 * * * \\
{[-4.75]}\end{array}$ & & & & $\begin{array}{c}0.03 * * * \\
{[6.18]}\end{array}$ \\
\hline Constant & $\begin{array}{l}0.21^{* *} \\
{[3.19]}\end{array}$ & $\begin{array}{c}0.41 \\
{[0.14]}\end{array}$ & $\begin{array}{c}0.51 \\
{[1.01]}\end{array}$ & $\begin{array}{c}0.41 \\
{[0.20]}\end{array}$ & $\begin{array}{c}0.66^{* * * *} \\
{[7.71]}\end{array}$ & $\begin{array}{l}0.22 * * * \\
{[21.71]}\end{array}$ & $\begin{array}{l}0.73^{* * * *} \\
{[41.31]}\end{array}$ & $\begin{array}{l}1.74 * * * * \\
{[18.02]}\end{array}$ \\
\hline$R^{2}$ & 0.48 & 0.41 & 0.46 & 0.39 & 0.52 & 0.49 & 0.52 & 0.59 \\
\hline Observations & 556 & 556 & 556 & 556 & 556 & 556 & 556 & 556 \\
\hline $\begin{array}{ll}\text { No. } & \text { of } \\
\text { countires }\end{array}$ & 35 & 35 & 35 & 35 & 35 & 35 & 35 & 35 \\
\hline $\begin{array}{l}\text { Huasman } \\
\text { test }\end{array}$ & & & & & $33.14(0.00)$ & $40.11(0.00)$ & $42.12(0.00)$ & $43.18(0.00)$ \\
\hline $\begin{array}{l}\text { Pesaran CD } \\
(P \text {-value })\end{array}$ & & & & & 0.41 & 0.39 & 0.14 & 0.12 \\
\hline
\end{tabular}

While it is basically depended on country-specific features, it could be inferred that institutional factors are critically conditional in explaining FDI - growth linkage in SSA countries. These findings are aligned with some previous views that the core view that the spillover effect of FDI on economic growth is conditional on some additional factors (especially institutional factors) within the FDI-recipient economy (Borensztein et al., 1998; Carkovic and Levine, 2003; Lin et al., 2014). Thus it must be emphasized that it may be somewhat difficult to disentangle the mediating effect of institutions on FDI - growth relationship across countries in the region. In consistency with the results obtained under Pooled OLS, all the institutional measures maintain their positive signs suggesting that in spite of the dire economic condition, an enabling framework for improved institutional quality will potentially mitigate adverse economic performance in the region. On the other hand, the inclusion of fixed effects model also eliminates the negative signs, except in column (i), attached to the FDI in the previous section. This is indeed in line with the proposition that through boosting investment, FDI could stimulate growth in the host countries (Choe, 2003; Sylwester, 2005; Sunde, 2017).

For robustness checks, Table 2 shows the results of Panel - Corrected Standard Error' (PCSE) Estimation. PCSE ensures that a model gives efficient and unbiased estimates when there is a possible serial and contemporaneous correlation. Thus, this approach is used to evaluate the validity and precision of results obtained through the panel regression analysis in Table 1. These results marry up with the original results as the major variables of interest exhibit almost the same signs. In addition, Table 3, for the one-step Difference and System GMM dynamic panel estimations, Arrelano-Bond test for the second order serial correlation, the results indicate 
the absence of second-order serial correlation in all the models. And regarding the number of instruments, in all, is less than the number of observations, while the test of overidentifying restrictions (Sargan test) shows that the instruments are valid. Thus, these satisfy the rule of thumb, as all required conditions are satisfied.

Table-2. Panel - Corrected Standard Error' (PCSE) Estimation.

\begin{tabular}{|c|c|c|c|c|}
\hline GDP(log) & Model (i) & Model (ii) & Model (iii) & Model (iv) \\
\hline FDI & $\begin{array}{l}-0.01 * * \\
{[-2.01]}\end{array}$ & $\begin{array}{l}-0.002 \\
{[-1.11]}\end{array}$ & $\begin{array}{l}-0.01^{*} \\
{[-1.61]}\end{array}$ & $\begin{array}{l}-0.02^{*} \\
{[-1.91]}\end{array}$ \\
\hline TRP(log) & $\begin{array}{c}0.54^{* * * *} \\
{[4.13]}\end{array}$ & $\begin{array}{c}0.39 * * * \\
{[5.10]}\end{array}$ & $\begin{array}{c}0.48 * * * \\
{[6.12]}\end{array}$ & $\begin{array}{c}0.51 * * * \\
{[5.03]}\end{array}$ \\
\hline $\mathrm{GCF}(\log )$ & $\begin{array}{c}-0.02 \\
{[-0.21]}\end{array}$ & $\begin{array}{c}-0.11 \\
{[-0.45]}\end{array}$ & $\begin{array}{c}-0.01 \\
{[-0.38]}\end{array}$ & $\begin{array}{c}-0.02 \\
{[-0.36]}\end{array}$ \\
\hline GOV & $\begin{array}{l}0.04 * * \\
{[2.15]}\end{array}$ & & & \\
\hline $\mathrm{COR}$ & & $\begin{array}{c}0.09 * * * \\
{[8.24]}\end{array}$ & & \\
\hline POL & & & $\begin{array}{c}0.20^{* * * *} * \\
{[5.31]}\end{array}$ & \\
\hline REG & & & & $\begin{array}{c}0.40^{* * * *} \\
{[6.53]}\end{array}$ \\
\hline FDI*GOV & $\begin{array}{c}-0.003 * * \\
{[-2.45]}\end{array}$ & & & \\
\hline FDI*COR & & $\begin{array}{l}-0.002 \\
{[-0.25]}\end{array}$ & & \\
\hline FDI*POL & & & $\begin{array}{c}0.01 \\
{[0.63]}\end{array}$ & \\
\hline FDI*REG & & & & $\begin{array}{l}-0.001 \\
{[-1.02]}\end{array}$ \\
\hline Constant & $\begin{array}{c}0.29^{* * * *} \\
{[9.13]}\end{array}$ & $\begin{array}{l}0.81 * * * \\
{[12.15]}\end{array}$ & $\begin{array}{l}0.25^{* * * *} \\
{[15.21]}\end{array}$ & $\begin{array}{c}0.15 * * * \\
{[7.61]}\end{array}$ \\
\hline Observations & 556 & 556 & 556 & 556 \\
\hline No. of countries & 35 & 35 & 35 & 35 \\
\hline
\end{tabular}

Following the results in Table 3, in the Difference GMM estimation, FDI is negative in column (i) and (ii) and only significant in column (i) while it is positive in column (ii) and (iv) and both are significant although narrowly in column (iv) the coefficients are still within the range of the fixed effects model estimation, but the weak significant may be slightly caused by the relatively standard error ${ }^{17}$. Also, in line with the results of the previous estimations, gross domestic capital formation is positively linked to growth. Although trade openness maintains its importance, institutional measures lost relevance and also indicate a negative sign in column (ii) and (iv) (control of corruption and regulatory quality). The same thing happens to the interaction terms of FDI with governance index and political stability (column (i) and (iii)). However, the interaction terms of FDI with control of corruption and regulatory quality suggest that both institutional measures are relevant in explaining FDI-growth nexus but with a paltry positive influence. In the System-GMM estimation, results somewhat relate with the panel regression analysis and Difference GMM, FDI is negatively associated (from column (i) - (iv)) with economic growth in SSA, but it is significantly important in explaining growth. However, the results show clearly that both trade openness and gross domestic capital formation more strongly induce SSA economies. Furthermore, the results show that institutional indicators (column (i), (ii) and (iv)) have a positive and significant association with growth in SSA, with the exemption of political stability (column (iii) that retards it, and it is also less significant. Essentially, the interaction of FDI with governance composite index indicates a positive coefficient. This confirms the mediating role of institutions in FDI - growth linkage. However, the interaction of FDI with the three individual indicators

${ }_{17}$ According to Deaton (1995) fixed effects can lead to considerable attenuation bias when there is measurement error and persistent independent variables. 
used (control of corruption, political stability and regulatory quality) produce a contrary account, as they all adversely affect the linkage. Overall, both the one-step Difference and System GMM, in light of dynamic relationship, show that the values of GDP per capita in the preceding period are crucial for explaining growth.

Table-3. One - Step Difference and System GMM Estimation.

\begin{tabular}{|c|c|c|c|c|c|c|c|c|}
\hline GDP (log) & & Differe & ce GMM & & & Syste & GMM & \\
\hline & (i) & (ii) & (iii) & (iv) & (i) & (ii) & (iii) & (iv) \\
\hline$G D P$ (lag) & $\begin{array}{c}0.68 * * * \\
{[8.53]}\end{array}$ & $\begin{array}{c}0.62 * * * \\
{[5.20]}\end{array}$ & $\begin{array}{c}0.67 \text { **** } \\
{[9.58]}\end{array}$ & $\begin{array}{c}0.45^{*} * * \\
{[6.60]}\end{array}$ & $\begin{array}{l}\text { O.18*** } \\
{[16.13]}\end{array}$ & $\begin{array}{l}0.38 * * * \\
{[18.13]}\end{array}$ & $\begin{array}{l}0.29 * * * \\
{[15.95]}\end{array}$ & $\begin{array}{l}0.18^{* * * *} \\
{[17.20]}\end{array}$ \\
\hline$F D I$ & $\begin{array}{c}-0.003 * * 1 \\
{[-3.13]}\end{array}$ & $\begin{array}{l}-0.01 * * \\
{[-2.16]}\end{array}$ & $\begin{array}{c}-0.01 \\
{[-1.14]}\end{array}$ & $\begin{array}{l}0.03^{*} \\
{[1.65]}\end{array}$ & $\begin{array}{l}-0.02^{* *} \\
{[-3.11]}\end{array}$ & $\begin{array}{c}-0.001 * * * \\
{[-3.12]}\end{array}$ & $\begin{array}{l}-0.01 * * \\
{[-2.51]}\end{array}$ & $\begin{array}{l}-0.04 * * \\
{[-2.57]}\end{array}$ \\
\hline$T R P(\log )$ & $\begin{array}{l}0.14^{* *} \\
{[3.19]}\end{array}$ & $\begin{array}{l}0.15^{* *} \\
{[2.49]}\end{array}$ & $\begin{array}{l}0.14^{* *} \\
{[2.46]}\end{array}$ & $\begin{array}{l}0.15 * * \\
{[2.48]}\end{array}$ & 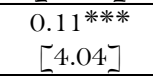 & $\begin{array}{c}0.13^{*} * * \\
{[7.50]}\end{array}$ & $\begin{array}{c}0.10^{* * *} * \\
{[5.04]}\end{array}$ & $\begin{array}{c}0.14 * * * \\
{[6.23]}\end{array}$ \\
\hline$G C F(\log )$ & $\begin{array}{c}0.01 \\
{[1.42]}\end{array}$ & $\begin{array}{l}0.01^{*} \\
{[1.66]}\end{array}$ & $\begin{array}{c}0.01 \\
{[1.28]}\end{array}$ & $\begin{array}{l}0.01^{*} \\
{[1.53]}\end{array}$ & $\begin{array}{l}0.01 * * 6 \\
{[2.55]}\end{array}$ & $\begin{array}{l}0.01 \text { * } \\
{[2.62]}\end{array}$ & $\begin{array}{l}0.01 * * \\
{[3.25]}\end{array}$ & $\begin{array}{l}0.01 \text { * } * \\
{[2.17]}\end{array}$ \\
\hline$G O V$ & $\begin{array}{l}0.004 \\
{[0.42]}\end{array}$ & & & & $\begin{array}{l}0.02 * * \\
{[2.79]}\end{array}$ & & & \\
\hline COR & & $\begin{array}{c}-0.01 \\
{[-1.19]}\end{array}$ & & & & $\begin{array}{l}0.04 * * \\
{[2.61]}\end{array}$ & & \\
\hline$P O L$ & & & $\begin{array}{c}0.002 \\
{[0.29]}\end{array}$ & & & & $\begin{array}{c}-0.01 \\
{[-0.55]}\end{array}$ & \\
\hline$R E G$ & & & & $\begin{array}{c}-0.02 \\
{[-1.12]}\end{array}$ & & & & $\begin{array}{l}\text { O.03** } \\
{[3.17]}\end{array}$ \\
\hline$F D I^{*} G O V$ & $\begin{array}{l}-0.002 \\
{[-0.12]}\end{array}$ & & & & $\begin{array}{c}0.01 \\
{[0.15]}\end{array}$ & & & \\
\hline$F D I^{*} C O R$ & & $\begin{array}{c}0.001^{* *} \\
{[2.49]}\end{array}$ & & & & $\begin{array}{l}-0.003^{*} \\
{[-1.78]}\end{array}$ & & \\
\hline$F D I^{*} P O L$ & & & $\begin{array}{c}0.001 \\
{[0.31]}\end{array}$ & & & & $\begin{array}{l}-0.002 \\
{[-0.11]}\end{array}$ & \\
\hline$F D I^{*} R E G$ & & & & $\begin{array}{l}0.01 \text { ** } \\
{[2.46]}\end{array}$ & & & & $\begin{array}{c}-0.02 \\
{[-0.99]}\end{array}$ \\
\hline Constant & & & & & $\begin{array}{l}0.23^{* * *} \\
{[3.25]}\end{array}$ & $\begin{array}{c}0.19^{*} * * * \\
{[4.19]}\end{array}$ & $\begin{array}{c}0.13 * * * \\
{[5.51]}\end{array}$ & $\begin{array}{c}0.21 * * * * \\
{[4.14]}\end{array}$ \\
\hline Observations & 485 & 485 & 485 & 485 & 522 & 522 & 522 & 522 \\
\hline No. of countires & 35 & 35 & 35 & 35 & 35 & 35 & 35 & 35 \\
\hline $\begin{array}{ll}\text { No. } & \text { of } \\
\text { instruments } & \\
\end{array}$ & 41 & 41 & 41 & 41 & 78 & 78 & 78 & 78 \\
\hline $\begin{array}{l}A \quad-\quad \text { Bond } \\
\text { AR(1) test } p- \\
\text { value }\end{array}$ & $-6.74(0.00)$ & $-6.71(0.00)$ & $-5.95(0.00)$ & $-6.01(0.00)$ & $-7.05(0.00)$ & $-5.98(0.00)$ & $-6.32(0.00)$ & $-6.29(0.00)$ \\
\hline $\begin{array}{l}A \quad-\quad \text { Bond } \\
\text { AR(2) test } p- \\
\text { value }\end{array}$ & $-1.60(0.11)$ & $-1.44(0.23)$ & $-1.39(0.11)$ & $-1.17(0.15)$ & $-1.53(0.13)$ & $-1.63(0.11)$ & $-1.61(0.12)$ & $-1.56(0.10)$ \\
\hline Sargan test & $23.35(0.41)$ & $31.21(0.33)$ & $36.10(0.51)$ & $37.14(0.26)$ & $37.23(0.43)$ & $34.72(0.26)$ & $42.19(0.21)$ & $39.13(0.20)$ \\
\hline
\end{tabular}

Figures in parentheses are /t-values/. (***), (**) \& $(*)$ indicate significance at $1 \%, 5 \%$ and $10 \%$ respectively.

Generally, in view of the extremely skewed distributions of FDI among SSA countries and typically commodity-based economies in the region, the bulk of FDI is in the primary sector (natural resources) ${ }^{18}$. Empirically, in such economies, an adverse correlation would be expected between FDI and growth (Alfaro, 2003). Hence, this accounts for the negative effect of FDI on growth in SSA. Nonetheless, all the governance dimensions are found to be paramount to growth enhancement in SSA, although with slightly varying degree ${ }^{19}$. In sum, in light of results, governance in SSA is pervasively feeble and has been ineffective in stimulating growth. This is largely responsible for the inability of SSA countries to attract FDI compared to other developing regions of the world (Jensen, 2003; Adeleke, 2014). More importantly, based on the System-GMM ${ }^{20}$ which is more robust and efficient, the interaction of FDI with aggregate governance index validates some initial propositions that suggest that

\footnotetext{
${ }_{18}$ By and large, resource-seeking FDI has a limited influence on economies (see Selhausen (2009)).

${ }^{19}$ Under System GMM, the insignificance of political stability variable could be attributed to the poor political system across countries in the region

${ }^{20}$ In the study, our conclusion is based on One Step System - GMM results, while the results of other techniques used serve as complementary evidence.
} 
governance seems to mediate in FDI-growth linkage. However, the absence of right conditions (poor governance practices) limits foreign investors' operation across countries which makes FDI inflows to go badly and ineffectively in the region. Thus, the quality of institutions counts in FDI-growth relationship in SSA, as the findings majorly suggest that the pervasiveness of weak institutions in SSA is the critical factor that has a negative effect on the development of the nexus between FDI and economic growth.

\section{CONCLUDING REMARKS}

In sub - Saharan Africa, prevalent weak institutions and the rising concern for improved business environment offer considerable leverage for enhancing the effectiveness of institutional framework, capital inflows and public investment efficiency. These have put SSA in the global spotlight in recent times. Hence, the study examines the mediating effect of governance on FDI - growth nexus in 35 SSA countries (2002 - 2017) employing a battery of recent econometric techniques. Specifically, the countries are; Angola, Benin, Burkina Faso, Botswana, Burundi, Cameroon, Central Africa Republic, Chad, Congo, Congo Dem. Rep, Cote d'lvoire, Equitoria Guinea, Gabon, Gambia, Ghana, Guinea, Guinea-Bissau, Kenya, Madagascar, Malawi, Mali, Mauritius, Mozambique, Namibia, Niger, Nigeria, Rwanda, Senegal, Sierra Leone, South Africa, Swaziland, Tanzania, Togo, Uganda and Zinbabwe.

In light of the analysis, all the governance dimensions (control of corruption, political stability and regulatory quality) including the aggregate governance index, although with slightly varying degree, have a significant positive effect on economic growth, indicating that institutions have a salutary impact on SSA economies, as enabling framework for improved institutional quality would potentially mitigate untoward economic performance in the region. Analogously, both trade openness and gross domestic capital formation are found to be significantly pertinent to growth-enhancing. SSA countries need to be well ingrained in the global investment frontier by stimulating their international trade activities as well as promoting domestic core investment policies through reorienting investment incentives. In contrast, by and large, an adverse correlation exists between FDI and growth in the region. Empirically, the extremely skewed distributions of FDI among SSA countries and typically commodity-based economies in the region have been the key inducing factor. More importantly, the pervasiveness of weak institutions in SSA is identified as a crucial case that has an inimical effect on the development of the nexus between FDI and economic growth. In African countries, most proactive government policies across SSA countries have been hampered by huge capacity gaps. In sum, the empirical evidence suggests that the essential ingredient for growth in Africa is effective governance and proactive institutional coordination.

Considering the lessons drawn from the findings, FDI - growth linkage would be enhanced by promoting a strong institutional environment that offers a good mechanism for attaining the actual FDI spillover potential through a policy framework that points the path towards cost-effective measures in SSA. Also, there should be core investment policies that would induce the private sector in consolidating government efforts and resources aimed at improving international competitiveness by diversifying the region's economies away from a protracted commodity - based.

Finally, it is pertinent to note that, like previous empirical studies, the study mainly relies on aggregate data of FDI; nonetheless, the impact of institutions on the development of the linkage between sector-specific FDI and growth may vary in SSA due to the level of absorptive capacity. Thus, future studies may concentrate on unpacking this puzzling empirical postulation.

Funding: This study received no specific financial support.

Competing Interests: The authors declare that they have no competing interests.

Contributors/Acknowledgement: Both authors contributed equally to the conception and design of the study. 


\section{REFERENCES}

Abdulla, A.R., M.M. Othman and Z. Hongzhong, 2012. An empirical study on the strategies to attract foreign direct investments in Tanzania. Journal on Innovation and Sustainability, 3(1): 43-52.Available at: https://doi.org/10.24212/21793565.2012v3i1 p43-52.

Abed, G. and S. Gupta, 2002. The economics of corruption: In governance, corruption, and economic performance. ed. by Abed, G, \& Gupta, S. Washington: International Monetary Fund.

Acemoglu, D., S. Johnson and J.A. Robinson, 2001. The colonial origins of comparative development: An empirical investigation. American Economic Review, 91(5): 1369-1401.Available at: https://doi.org/10.1257/aer.91.5.1369.

Acemoglu, D., S. Johnson and J.A. Robinson, 2005b. Institutions as a fundamental cause of long-run growth. Handbook of Economic Growth, 1: 385-472.Available at: https://doi.org/10.1016/s1574-0684(05)0 1006-3.

Acemoglu, D. and J. Robinson, 2005a. Unbundling institutions. Journal of Political Economy, 113(5): 949-995.

Adeleke, I.A., 2014. FDI-growth nexus in Africa: Does governance matter? International Review of Financial Analysis, 21: 8189.

Ajide, K., O. Adeniyi and I. Raheem, 2014. Does governance impact on the foreign direct investment-growth nexus in SubSaharan Africa?. Zagreb International Review of Economics \& Business, 17(2): 71-81.

Akinlo, A.E., 2004. Foreign direct investment and growth in Nigeria: An empirical investigation. Journal of Policy Modeling, 26(5): 627-639.

Al-Iriani, M., 2007. Foreign direct investment and economic growth in the GCC countries: A causality investigation using heterogeneous panel analysis. Topics in Middle Eastern and North African Economies, 9(1): 1-31.

Alexious, C., P. Tsaliki and H.R. Osman, 2014. Institutional quality and economic growth: Empirical evidence from the Sudanese economy. Economic Annals, 59(203): 137-199.

Alfaro, L., 2003. Foreign direct investment and growth: Does the sector matter? Technical Report, Working Paper, Harvard Business School.

Alfaro, L., A. Chanda, S. Kalemli-Ozcan and S. Sayek, 2006. How does foreign direct investment promote economic growth? Exploring the effects of financial markets on linkages. National Bureau of Economic Research, WP, 12522.

Almfraji, M.A. and M.K. Almsafir, 2014. Foreign direct investment and economic growth literature review from 1994 to 2012. Procedia-Social and Behavioral Sciences, 129: 206-2 13.Available at: https://doi.org/10.1016/j.sbspro.2014.03.668.

Arellano, M. and O. Bover, 1995. Another look at the instrumental variable estimation of error-components models. Journal of Econometrics, 68(1): 29-51.Available at: https://doi.org/10.1016/0304-4076(94)01642-d.

Asiedu, E., 2002. On the determinants of foreign direct investment to developing countries: Is Africa different?. World Development, 30(1): 107-1 19.Available at: https://doi.org/10.1016/s0305-750x(01)00100-0.

Balasubramanyam, V.N., M. Salisu and D. Sapsford, 1996. Foreign direct investment and growth in EP and IS countries. The Economic Journal, 106(434): 92-105.

Behera, S.R. and D.P. Dash, 2017. The effect of urbanization, energy consumption, and foreign direct investment on the carbon dioxide emission in the SSEA (South and Southeast Asian) region. Renewable and Sustainable Energy Reviews, 70: 96106.Available at: https://doi.org/10.1016/j.rser.2016.11.201.

Blomstrom, M. and A. Kokko, 2003. The economics of foreign direct investment incentives. NBER Working Paper, 9489.

Blundell, R. and S. Bond, 1998. Initial conditions and moment restrictions in dynamic panel data models. Journal of Econometrics, 87(1): 115-143.Available at: https://doi.org/10.1016/s0304-4076(98)00009-8.

Borensztein, E., J. De Gregorio and J.-W. Lee, 1998. How does foreign direct investment affect economic growth? Journal of International Economics, 45(1): 115-135.Available at: https://doi.org/10.1016/so022-1996(97)00033-0.

Bruno, R.L. and N.F. Campos, 2013. Re-examining the conditional effects of foreign direct investment. Available from http://papers.ssrn.com.

Carkovic, M. and R. Levine, 2003. Does foreign direct investment accelerate economic growth? University of Minnesota Discussion Paper, May. 
Chauvet, L. and P. Collier, 2004. Development effectiveness in fragile states: Spillovers and turnarounds. Centre for the Study of African Economies, Department of Economics, Oxford University (Mimeo).

Choe, J.I., 2003. Do foreign direct investment and gross domestic investment promote economic growth? Review of Development Economics, 7(1): 44-57.Available at: https://doi.org/10.1111/1467-9361.00174.

Chowdhury, A. and G. Mavrotas, 2006. FDI and growth: what causes what?. World Economy, 29(1): 9-19.Available at: https://doi.org/10.1111/j.1467-9701.2006.00755.x.

Crespo, N. and M.P. Fontoura, 2007. Determinant factors of FDI spillovers-what do we really know?. World Development, 35(3): 410-425.Available at: https://doi.org/10.1016/j.worlddev.2006.04.001.

Cuervo-Cazurra, A., 2008. Better the devil you don't know: Types of corruption and FDI in transition economies. Journal of International Management, 14(1): 12-27.Available at: https://doi.org/10.1016/j.intman.2007.02.003.

Daniele, V. and U. Marani, 2006. Do institution matter for foreign direct investment? A comparative analysis of MENA countries. MPRA Paper No.2426.

De Backer, K. and L. Sleuwaegen, 2003. Does foreign direct investment crowd out domestic entrepreneurship? Review of Industrial Organization, 22(1): 67-84.

Deaton, A., 1995. Data and econometric tools for development analysis. Handbook of Development Economics, 3: $1785-1882$.

Dollar, D. and A. Kraay, 2000. Property rights, political rights and the development of poor countries in the post - colonial period. World Bank Working Papers.

Driffield, N. and J.H. Love, 2007. Linking FDI motivation and host economy productivity effects: Conceptual and empirical analysis. Journal of International Business Studies, 38(3): 460-473.Available at: https://doi.org/10.1057/palgrave.jibs.8400268.

Dunning, J.H., 1994. Reevaluating the benefits of foreign direct investment. Transnational Corporations, 3(1).

Durham, J.B., 2004. Absorptive capacity and the effects of foreign direct investment and equity foreign portfolio investment on economic growth. European Economic Review, 48(2): 285-306.Available at: https://doi.org/10.1016/s0014$2921(02) 00264-7$.

Dutt, A.K., 1997. The pattern of direct foreign investment and economic growth. World Development, 25(11): 19251936.Available at: https://doi.org/10.1016/s0305-750x(97)00081-8.

Duttaray, M., A.K. Dutt and K. Mukhopadhyay, 2008. Foreign direct investment and economic growth in less developed countries: An empirical study of causality and mechanisms. Applied Economics, 4O(15): 1927-1939.Available at: https://doi.org/10.1080/00036840600949231.

Farole, T. and D. WinklerMaking, 2014. Foreign direct investment work for Sub-Saharan Africa: Local spillovers and competitiveness in global value chains. The World Bank.

Fosu, O. and O.E. Magnus, 2006. Bounds testing approach to cointegration: An examination of FDI, trade and growth relationship. American Journal of Applied Sciences, 3(11): 2079 - 2085.Available at: https://doi.org/10.3844/ajassp.2006.2079.2085.

Global Finance Magazine, 2018. Top countries for foreign direct investment. Global Finance Magazine.

Globerman, S., D. Shapiro and Y. Tang, 2004. Governance and foreign direct investment in emerging and transition European countries. Available from https://cbe.wwu.edu/.

Gorodnichenko, Y., J. Svejnar and K. Terrell, 2007. When does FDI have positive spillovers? Evidence from 17 emerging market economies. Institute for the Study of Labor, Bonn, Germany, IZA Discussion Paper 3079.

Greenaway, D. and R. Kneller, 2007. Firm heterogeneity, exporting and foreign direct investment. The Economic Journal, 117(517): F134-F161.Available at: https://doi.org/10.1111/j.1468-0297.2007.02018.x.

Grigoli, F. and Z. Mills, 2014. Institutions and public investment: An empirical analysis. Economics of Governance, 15(2): 131153.

Grossman, G.M. and E. Helpman, 1991. Quality ladders in the theory of growth. The Review of Economic Studies, 58(1): 4361.Available at: https://doi.org/10.2307/2298044. 
Gui-Diby, S.L., 2014. Impact of foreign direct investments on economic growth in Africa: Evidence from three decades of panel data analyses. Research in Economics, 68(3): 248-256.Available at: https://doi.org/10.1016/j.rie.2014.04.003.

Hall, R.E. and C.I. Jones, 1999. Why do some countries produce so much more output per worker than others? The Quarterly Journal of Economics, 114(1): 83-116.Available at: https://doi.org/10.1 162/003355399555954.

Hayat, A., 2016. Foreign direct investment, institutional framework and economic growth. Munich Personal RePEC Archieve No. 74563.

Jensen, N.M., 2003. Democratic governance and multinational corporations: Political regimes and inflows of foreign direct investment. International Organization, 57(3): 587-616.Available at: https://doi.org/10.1017/s0020818303573040.

Jugurnath, B., N. Chuckun and S. Farzel, 2016. Foreign direct investment andeconomic growth in Sub-Saharan Africa: An empirical analysis. Journal of Scientific Research Publishing: 1 - 10.

Kamara, Y.U., 2013. Foreign direct investment and growth in Sub-Saharan Africa: What are the channels? University of Kansas.

Kaufmann, D., A. Kraay and M. Mastruzzi, 2010. The worldwide governance indicators: Methodology and analytical issues. Available from www.govindicators.org [Accessed 19 April 2016].

Krugman, P., 2009. The return of depression economics and the crisis of 2008. New York: Norton \& Company.

Li, X. and X. Liu, 2005. Foreign direct investment and economic growth: An increasingly endogenous relationship. World Development, 33(3): 393-407.Available at: https://doi.org/10.1016/j.worlddev.2004.11.001.

Lin, J., M. Seyoum and R. Wu, 2014. Foreign direct investment: The case of developing African economies. Springer Science Business Media Dordrecht.

Liu, L.G. and R. Premus, 2000. Global economic growth: Theories, research, studies, and annotated bibliography. London: Greenwood Press.

Lucas, J.R.E., 1988. On the mechanics of economic development. Journal of Monetary Economics, 22(1): 3-42.

Masron, T.A. and E. Nor, 2013. FDI in ASEAN-8: Does institutional quality matter?. Applied Economics Letters, 20(2): 186189.Available at: https://doi.org/10.1080/13504851.2012.687090.

Mehanna, R.-A., Y. Yazbeck and L. Sarieddine, 2010. Governance and economic development in MENA countries: Does oil affect the presence of a virtuous circle?. Journal of Transnational Management, 15(2): 117-150.Available at: https://doi.org/10.1080/15475778.2010.481250.

Mengistu, B. and S. Adams, 2007. Foreign direct investment, governance and economic development in developing countries. The Journal of Social, Political and Economic Studies, 32(2): 223-249.

Meyer, K.E. and E. Sinani, 2009. When and where does foreign direct investment generate positive spillovers? A meta-analysis. Journal of International Business Studies, 40(7): 1075-1094.Available at: https://doi.org/10.1057/jibs.2008.111.

Mishra, A. and K. Daly, 2007. Effect of quality of institutions on outward foreign direct investment. The Journal of International Trade \& Economic Development, 16(2): 231-244.Available at: https://doi.org/10.1080/09638190701325573.

Nondo, C., M.S. Kahsai and Y.G. Hailu, 2016. Does institutional quality matter in foreign direct investment?: Evidence from Sub-Saharan African countries. African Journal of Economic and Sustainable Development, 5(1): 12-30.Available at: https://doi.org/10.1504/ajesd.2016.074441.

North, D.C., 1990. Institutional change and economic performance. New York: Cambridge University Press.

Onyeiwu, S. and H. Shrestha, 2004. Determinants of foreign direct investment in Africa. Journal of Developing Societies, 20(1-2): 89-106.

Parks, R.W., 1967. Efficient estimation of a system of regression equations when disturbances are both serially and contemporaneously correlated. Journal of the American Statistical Association, 62(318): 500-509.Available at: https://doi.org/10.2307/2283977.

Pedersen, P. and D. McCormick, 1999. African business systems in a globalizing world. The Journal of Modern African Studie,s, 37(1): 109-135.

Pegkas, P., 2015. The impact of FDI on economic growth in Eurozone countries. The Journal of Economic Asymmetries, 12(2): 124-132.Available at: https://doi.org/10.1016/j.jeca.2015.05.001. 
Petrakos, G., P. Arvantidis and S. Pavles, 2007. Determinants of economic growth: The experts' view. Discussion Paper Series, $13(10): 245-276$.

Raheem, I. and M. Oyinlola, 2013. Foreign direct investment, governance and economic growth trilogy: New evidence from ECOWAS countries. Journal of Global \& Science Issues, 1(2).

Ray, S., 2012. Impact of foreign direct investment on economic growth in India: A co integration analysis. Advances in Information Technology and Management, 2(1): 187-201.

Romer, P.M., 1986. Increasing returns and long-run growth. Journal of Political Economy, 94(5): 1002-1037.Available at: https://doi.org/10.1086/261420.

Roodman, D., 2009. How to do xtabond2: An introduction to difference and system GMM in Stata. The Stata Journal, 9(1): 86136.Available at: https://doi.org/10.1177/1536867x0900900106.

Sarwar, S., M. Siddiqi and A. Butt, 2013. Role of institutions and economic growth in Asian countries. Developing Country Studies, 3(2): 80-90.

Sayan, S., 2009. Econmic performance in the Middle East and North Africa: Institutions, corruption and reform. London (UK): Routledge Publishers. pp: 224.

Selhausen, F.M.Z., 2009. On geography and institutions as determinants of foreign direct investment. A cross country comparative analysis of Sub-Saharan African relative to developing countries (No. 200906). Chair of International Cooperation and Ibero-America (COIBA), University of Cantabria.

Shaikh, F.M. and A. Shar, 2010. Causality relationship between foreign direct investment, trade and economic growth in Pakistan. Asian Social Science, 6(9): 82-89.

Spencer, J.W., 2008. The impact of multinational enterprise strategy on indigenous enterprises: Horizontal spillovers and crowding out in developing countries. Academy of Management Review, 33(2): 341-361.Available at: https://doi.org/10.5465/amr.2008.31193230.

Stein, E. and C. Daude, 2002. Institutions, integration and the location of FDI, in new horizons of foreign direct investment. OECD global forum, international investment. Paris: OECD.

Subasat, T. and S. Bellos, 2013. Governance and foreign direct investment in Latin America: A panel gravity model approach. Latin American Journal of Economics, 50(1): 107-131.Available at: https://doi.org/10.7764/laje.50.1.107.

Sunde, T., 2017. Foreign direct investment, exports and economic growth: ADRL and causality analysis for South Africa. Research in International Business and Finance, 41: 434-444.Available at: https://doi.org/10.1016/j.ribaf.2017.04.035.

Sylwester, K., 2005. Foreign direct investment, growth and income inequality in less developed countries. International Review of Applied Economics, 19(3): 289-300.Available at: https://doi.org/10.1080/02692170500119748.

UNCTAD, 2017. World investment report: Investment and the digital economy. United Nations Conference on Trade and Development, New York and Geneva: United Nations.

UNCTAD, 2018. World investment report: Investment and new industrial policies. United Nations Conference on Trade and Development, New York and Geneva: United Nations.

Valeriani, E. and S. Peluso, 2011. The impact of institutional quality on economic growth and development: An empirical study. Journal of Knowledge Management, Economics and Information Technology, 1(6): 1-25.

Verspagen, B., 2012. Stylized facts of governance, institutions and economic development: Exploring the institutional profiles database. UNU-MERIT, WP, 36.

Wan, X., 2010. A literature review on the relationship between foreign direct investment and economic growth. International Business Research, 3(1): 52.Available at: https://doi.org/10.5539/ibr.v3n1p52.

Wang, M. and M.S. Wong, 2009. Foreign direct investment and economic growth: The growth accounting perspective. Economic Inquiry, 47(4): 701-7 10.Available at: https://doi.org/10.1111/j.1465-7295.2008.00133.x.

Williamson, O.E., 1985. The economic institutions of capitalism. New York: Free Press.

Windmeijer, F., 2005. A finite sample correction for the variance of linear efficient two-step GMM estimators. Journal of Econometrics, 126(1): 25-51.Available at: https://doi.org/10.1016/j.jeconom.2004.02.005. 
World Bank, 2018. World development indicator. Washington D. C.: World Bank.

Yalta, A.Y., 2013. Revisiting the FDI-led growth hypothesis: The case of China. Economic Modelling, 31: 335-343.Available at: https://doi.org/10.1016/j.econmod.2012.11.030.

Zouhaier, H. and M.K. Kefi, 2012. Institutions and economic growth. Asian Economic and Financial Review, 2(7): 795-812.

Views and opinions expressed in this article are the views and opinions of the author(s), International Journal of Business, Economics and Management shall not be responsible or answerable for any loss, damage or liability etc. caused in relation to/arising out of the use of the content. 